
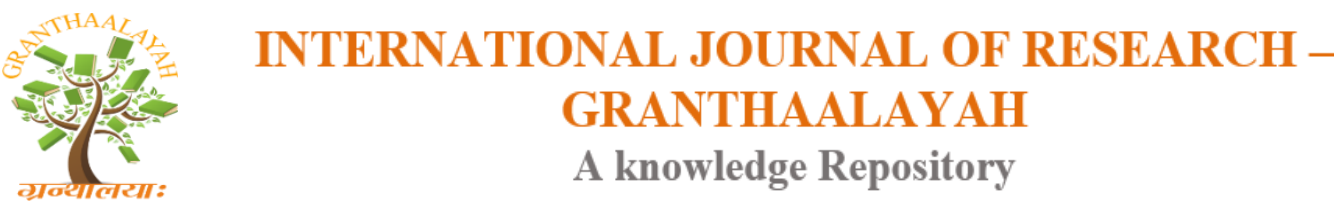

Social

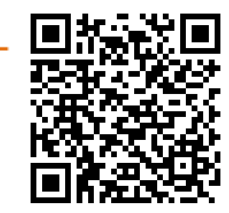

\title{
PERCEPTION OF TEACHER INVOLVEMENT IN TEACHING AND ITS EFFECT ON SCHOLASTIC ACHIEVEMENT AMONG HIGHER SECONDARY STUDENTS
}

\author{
Anu John. P.C. ${ }^{1}$, P.D. Vandana Devi ${ }^{2}$ \\ ${ }^{* 1}$ M.Ed Scholar, RVS College of Education, India \\ 2 Assistant Professor, RVS College of Education, India
}

DOI: https://doi.org/10.29121/granthaalayah.v5.i5(SE).2017.1981

\begin{abstract}
The paper is an attempt to find the effect between perception of teacher involvement in teaching and scholastic achievement of the selected Higher Secondary students. In the present study survey method was used. The investigator adopted the survey method to study the relationship between perception of teacher involvement in teaching and scholastic achievement Investigator selected only Higher Secondary students and 30 teachers as sample in Coimbatore district using stratified random sampling. The findings reveal that there is a mild positive relationship between social intelligence and academic achievement among the selected arts group students at Higher Secondary level.
\end{abstract}

Keywords: Teacher; Higher Secondary Students; Achievement; Perception.

Cite This Article: Anu John. P.C., and P.D. Vandana Devi. (2017). "PERCEPTION OF TEACHER INVOLVEMENT IN TEACHING AND ITS EFFECT ON SCHOLASTIC ACHIEVEMENT AMONG HIGHER SECONDARY STUDENTS." International Journal of Research - Granthaalayah, 5(5)SE, 118-121. 10.29121/granthaalayah.v5.i5(SE).2017.1981.

\section{Introduction}

The teacher plays multiple roles in the school. The role of teacher is assessed in terms of his/her attendance in the class, completion of the course and interpersonal relation in the school. Till now, hardly any indicator is developed to assess the performance of teacher on the basis of learning achievement of the student. . The teacher plays multiple roles in the school. The role of teacher is assessed in terms of his/her attendance in the class, completion of the course and interpersonal relation in the school. Till now, hardly any indicator is developed to assess the performance of teacher on the basis of learning achievement of the student. The emergence of a globalized world underscoring a framework of competition, and coupled with the pressures of an exploding knowledge base, has given birth to new challenges for schools as social institutions all over the world. New demands are placed on the school, often in addition to the existing ones, to 
be equipped with current knowledge and modern methods of acquiring new knowledge. The paper is an attempt to find the effect between perception of teacher involvement in teaching and scholastic achievement of the selected Higher Secondary students.

\section{Method}

In the present study survey method was used. Survey refers to gather information by individual samples so as to learn about the whole thing. The investigator adopted the survey method to study perception of teacher involvement in teaching and it effects scholastic achievement among higher secondary students. For the present study the investigator selected y 6 schools in and around Coimbatore. Investigator selected 150 higher secondary students and 30 teachers in this area using simple random sampling technique.

\section{Hypothesis: 1}

There will be a difference in the level of perception of teacher involvement in teaching among school teachers.

Table 1: Frequency and percentage difference in perception of teacher in teaching among school teachers.

\begin{tabular}{|c|c|c|c|c|c|c|c|c|}
\hline \multicolumn{9}{|c|}{ PERCEPTION OF TEACHER INVOLVEMENT IN TEACHEING } \\
\hline \multicolumn{3}{|c|}{ Low } & \multicolumn{3}{|c|}{ Moderate } & \multicolumn{3}{|c|}{ High } \\
\hline Q1 & $\mathbf{F}$ & $\%$ & Q2 & $\mathbf{F}$ & $\%$ & Q3 & $\mathbf{F}$ & $\%$ \\
\hline 52 & 10 & $33.33 \%$ & 56 & 12 & $40 \%$ & 61 & 8 & $26.66 \%$ \\
\hline
\end{tabular}

Table 1 exhibits the result of perception of teacher involvement in teaching among school teachers. According to the table totally $33.33 \% \%$ of the school teacher belong to low level of perception of teacher involvement in teaching, $40 \%$ of the school teachers belong to moderate level of perception of teacher involvement in teaching, $26.6 \%$ of the school teachers belong to high level of perception of teacher involvement in teaching. So the hypothesis No: 1 is accepted. Thus it is inferred that there is a difference in the level of perception of teacher involvement in teaching among school teachers.

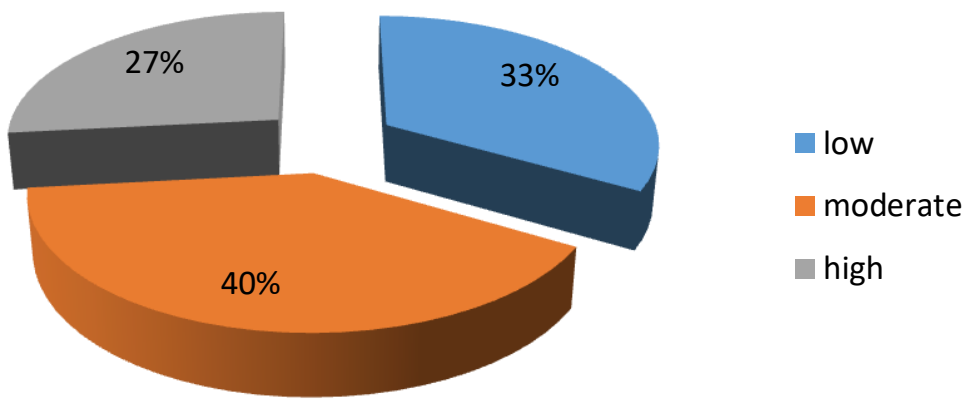

Chart 1: frequency and percentage difference in perception of teacher involvement in teaching among school teachers 


\section{Hypothesis: 2}

There will be a difference in the level of scholastic achievement among higher secondary school student.

Table 2: Frequency and percentage difference in scholastic achievement among higher secondary school student.

\begin{tabular}{|l|l|l|l|l|l|l|l|l|}
\hline SCHOLASTIC ACHIEVEMENT \\
\hline Low & \multicolumn{7}{|l|}{ Moderate } & High \\
\hline Q1 & F & \% & Q2 & F & \% & Q3 & F & \% \\
\hline 32 & 42 & $28 \%$ & 43 & 70 & $46.33 \%$ & 68 & 38 & 25.33 \\
\hline
\end{tabular}

Table 2 exhibits the result of scholastic achievement among higher secondary school student. According to the table totally $28 \%$ of the higher secondary students belong to low level of scholastic achievement, $46.33 \%$ of the higher secondary students belong to moderate level of scholastic achievement, $25.33 \%$ of the higher secondary students belong to high level of scholastic achievement. So the hypothesis No: 2 is accepted. Thus it is inferred that there is a difference in the level of scholastic achievement among higher secondary school student.

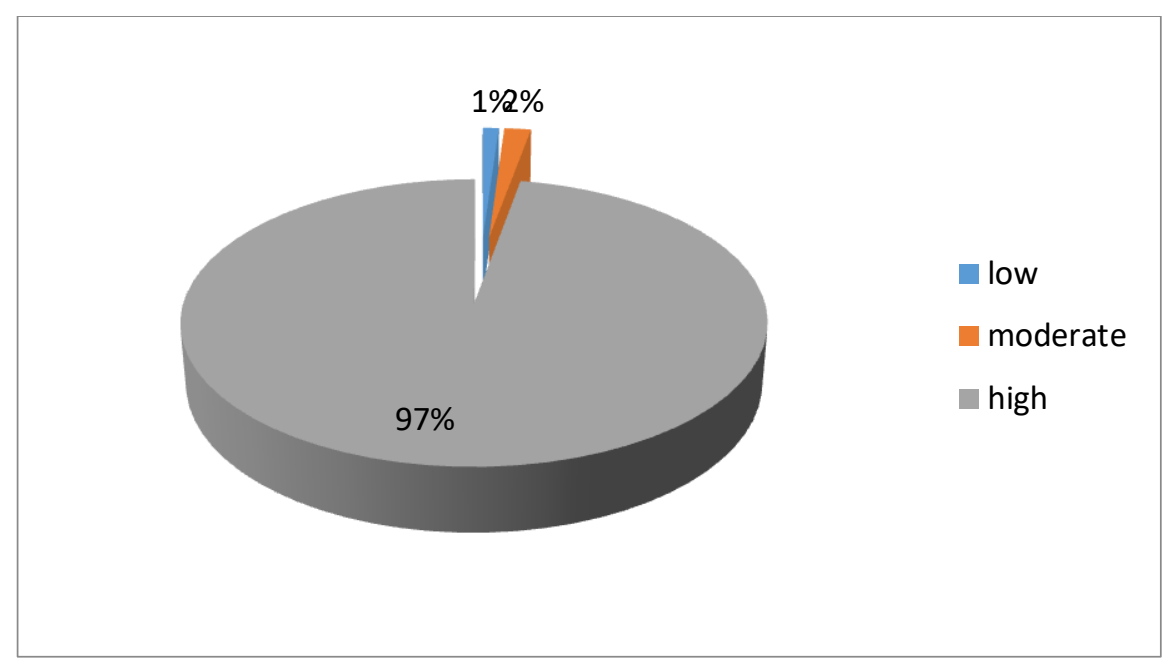

Chart 2: frequency and percentage difference in scholastic achievement among higher secondary school students

\section{Hypothesis: 3}

There will be a significant relationship between teacher involvement in teaching and scholastic achievement of the Higher Secondary students.

Table 3: Relationships between teacher involvement in teaching and scholastic achievement of the Higher Secondary students.

\begin{tabular}{|l|l|l|l|l|}
\hline VARIABLES 'r' Value & 'p' Value & Result \\
\hline $\begin{array}{l}\text { Perception of teacher } \\
\text { involvement in teaching }\end{array}$ & 30 & 0.243 & 0.195 & N.S \\
\hline Scholastic achievement & 150 & & & \\
\hline
\end{tabular}


The above table 3 shows the relationship between perception of teacher involvement in teaching and scholastic achievement of the Higher Secondary students. According to this table the correlation value of perception of teacher involvement in teaching and scholastic achievement is 0.243 which implies that that there is a mild positive relationship between perception of teacher involvement in teaching and scholastic achievement of the Higher Secondary students.

\section{Conclusion}

The findings reveal that there is a mild positive relationship which is considered as not significant between perception of teacher involvement in teaching and scholastic achievement among the Higher Secondary students. Also it is found that the school teachers possess moderate a level of perception of teacher involvement in teaching. And it is found that the higher secondary school students have a moderate level of scholastic achievement.

\section{References}

[1] Bhasin, Chanchal (1998): Teaching Attitude and its Relationship with Teaching Effectiveness of the Higher Secondary School Teachers in Relation to the Modern Community. Fifth Survey of Educational Research. (1982-92). Vol.11New Delhi : NCERT.

[2] Golden, S. A. R. (2011). Problems and Prospectus of Distance Learning. Bharathidhasan University, 343, 344.

[3] Golden, S. A. R. (2016). RURAL STUDENTS' ATTITUDE TOWARDS ENGLISH AS MEDIUM OF INSTRUCTION IN HIGHER EDUCATION-AN ANALYSIS. International Journal of Research, 3, 1-10.

[4] Golden, S. A. R. (2017). Attitude of Students and Teachers towards E-Learning-An Analysis. Recent Research in Social Science \& Humanities, 1, 5-10.

[5] Golden, S. A. R. (2017). Recent Research in Social Sciences \& Humanities. EduPedia Publications (P) Ltd.

[6] Mangal, S.K. (1982) : Teacher Adjustment Inventory (TAI).

[7] Manitoba Council for International Education (MCIE). (n.d.). Education in Manitoba. Retrieved November 11, 2013 from http://www.mcie.ca/

[8] Marsh, H. \& Kleitman, S. (2003). School athletic participation: Mostly gain with little pain.

[9] Regi, S. B., \& Golden, S. A. R. (2014). A Study On Attitude Of Employee Towards Working Environment With Special Reference To RR Pvt Ltd. Review Of Research, 2 (2), 1, 5.

[10] Regi, S. B., \& Golden, S. A. R. (2014). A Study On Educational Loan Availed By Students In Trichy City. Journal Of International Academic Research For Multidisciplinary (Jiarm), 2 (1).

[11] Schunk, D. H. (2000). Learning theories: An educational perspective (3rd ed.). Upper Saddle.

[12] Shankutla, K.S and Sabapathy Tara(1999): Teacher Adjustment as Related to Interest in and Attitude Towards Teaching . Indian Educational Abstract, Vol. 1, No. 1, New Delhi: NCERT.p.91. 